DOI https://doi.org/10.30525/978-9934-26-180-0-14

\title{
PROVERBS AS PHRASEOLOGICAL MEANS OF EXPRESSING PESSIMISM
}

\author{
Boichuk V. M. \\ Candidate of Philological Sciences, \\ Senior Lecturer at the Department of Philology, \\ The Municipal Higher Educational Institution \\ «Lutsk Pedagogical College» of the Volyn Regional Council \\ Yefremova N. V. \\ Candidate of Philological Sciences, Associate Professor, \\ Associate Professor at the Conversational English Department \\ Lesya Ukrainka Volyn National University \\ Lutsk, Ukraine
}

Broad understanding of phraseology suggests that proverbs are necessary components of the phraseological system of any language [1], thus having a certain potential to be used in pessimistic utterances. Proverb is a «succinct and pithy saying in general use, expressing commonly held ideas and beliefs» [7]. Proverbs as clichéd, aphoristic and sententious units reproduced without significant changes in communicative situations, contain implicitly wider as compared to explicitly expressed, factual and evaluative-aesthetic information.

The semantic analysis of proverbs $[4 ; 5 ; 6]$ has helped to indicate the semes of pessimism that reveal their potential ability to express qualitative features of pessimism in speech. It has been found that $47.3 \%$ of the proverbs under analysis explicate only one qualitative feature of pessimism in speech. The rest $(52.7 \%)$ serve to express a set of qualitative features of pessimism.

One qualitative feature of pessimism is implemented in speech by proverbs, which express: 1) basic features of pessimism: «misfortune» - Wednesday's child is full of woe; «failure» - a miss is as good as a mile; it's (just) one thing after another; it's the same old story; marry at haste and repent at leisure; marry in may, rue for aye; small choice in rotten apples; when poverty comes in at the door, love flies out of the window; «negative expectations» - hope for the best and prepare for the worst; bread always falls buttered side down; hope is a good breakfast but a bad supper; many go out for wool and come home shorn; shit happens; sing before breakfast, cry before night; sorrow comes unsent for; the best-laid schemes of mice and men gang aft a-glay; «uncertainty» - don't shout until you are out of the woods; go farther and fare worse; if you can't run with 
the big dogs, stay under the porch; let them laugh that win; little boats should stay close to shore; 2) adjacent features of pessimism: «disappointment»-the gods send nuts to those who have no teeth; the more things change, the more they stay the same; there's nothing new under the sun; «dissatisfaction» - jam tomorrow and jam yesterday, but never jam today; «loneliness» - a great city, a great solitude; «negative attitude» - children are certain cares, but uncertain comforts; clergymen's sons always turn out badly.

The combination of two qualitative features of pessimism has been found out in the semantics of proverbs implementing in speech the mixture of both basic and adjacent features of pessimism: 1) basic features of pessimism: «failure» + «negative expectations» - a burnt child dreads the fire; all bad things come in threes; an ill beginning makes an ill ending; bread always falls buttered side down; if anything can go wrong, it will; if the blind lead the blind, both shall fall into the ditch; once bitten, twice shy; once burned, twice shy; the weakest go to the wall; the writing is on the wall; there's many a slip between cup and lip; «hopelessness» + «negative expectations»-death defies the doctor; death have no calendar; every door may be shut but the death's door; he that lives in hope dances to an ill tune; he that lives on hope will die fasting; it'll all be the same in a hundred years; life is no bed of roses; "distrust» + «disbelief»" - believe only half of what you see and nothing you hear; trust not a new friend nor an old enemy; 2) adjacent features of pessimism «disappointment»+ «dissatisfaction»: life's a bitch, and then you die.

Arbitrary combination of two qualitative features of pessimism, belonging to different levels has been observed in such proverbs: 1) basic feature of pessimism + adjacent feature of pessimism: «sadness» + «negative attitude» misery loves company; «misfortune» + «anxiety» - a light purse makes a heavy heart; «misfortune» + «disappointment»-all good things must come to an end; «hopelessness» + «disappointment» - blessed are they who expect nothing, for they shall not be disappointed; 2) basic feature of pessimism + related feature of pessimism: «negative expectations» + «suffering» - we must eat a peck of dirt before we die; 3) adjacent feature of pessimism + related feature of pessimism: «suffering»+ «anxiety»-hope deferred makes the heart sick.

We have singled out the proverbs which tend to implement in speech three qualitative features of pessimism: 1) basic features of pessimism: «hopelessness» + «uncertainty» + «disbelief» - if a pig had wings, it might fly; if ifs and ands were pots and pans, there'd be no work for tinkers; if the sky falls, we shall catch larks; if wishes were horses, beggars would ride; one swallow doesn't make a summer; «failure» + «hopelessness» + «negative expectations»- it never rains but it pours; it's just one of those things; misfortunes never come singly; 2) basic features of pessimism + adjacent feature 
of pessimism: «hopelessness» + «disbelief» + «anxiety» - not in the month of Sundays.

These data suggest that proverbs explicate a limited number of qualitative features of pessimism (15 of 40). This may be explained by the conciseness, accuracy and expressiveness of proverbs as units that reflect a clear system of moral and ethical norms and certain stereotypes.

Thus, being metaphorical, clichéd and emotional proverbs tend to emphasize the pessimistic worldview of the speaker. Transparency of actualization of the qualitative features of pessimism contributes to the specificity of speech realization of pessimism. For example:

"It's all over now,» said Lewis, settling into a chair.

Mrs. Zimmermann looked at him strangely. "What do you mean?»

"That was the third thing," explained Lewis. "The Curse of Three, remember? I got clocked by a foul ball, I lost my allowance, and now I've sprained my ankle. Bad things come in threes, and this is the last one.» /.../

"No, I read it in an old book,» said Lewis. "The book called it the Curse of Three. Rose Rita says it's nonsense, but I've had a feeling something bad was going to happen» $[8$, p. 96].

The semantic analysis of the proverb «all bad things come in threes» makes it possible to single out the semes of pessimism «two similar occurrences (bad)» та «inevitably followed by a third (bad occurrence)», which indicate the speech realization of such basic features of pessimism as «failure», «negative expectations» (All bad things come in threes - according to popular superstition, two similar occurrences (bad) are inevitably followed by a third). The contextual marker of pessimism "It's all over now» complements these features with an indication of the speaker's hopelessness and frustration. The contextual marker of pessimism «a feeling something bad was going to happen» serves to reinforce the speaker's bad premonitions, once again emphasizing in speech the basic feature of pessimism «negative expectations». The speaker's recounting of all his failures ( II got clocked by a foul ball, I lost my allowance, and now I've sprained my ankle») reinforces the pessimistic tonality of the utterance.

The semes of pessimism «failure» and «negative expectations», identified in the semantic structure of the proverbs under study, indicate the speech realization of pessimism as an attributional style [2]. For example: a burnt child dreads the fire; all bad things come in threes; an ill beginning makes an ill ending; bread always falls buttered side down; he that lives in hope dances to an ill tune; it's (just) one thing after another; it's just one of those things; it's the same old story; once bitten, twice shy; the more things change, the more they stay the same та ін. 
Proverbs expressing defensive pessimism [3], reflect such basic features of pessimism as «hopelessness», «uncertainty», «negative expectations». Anxiety which is connected with the disability to control the situation, low expectations, despite the positive previous experience, are the factors that underlie the semantics of such proverbs: blessed are they who expect nothing, for they shall not be disappointed; don't shout until you are out of the woods; if you can't run with the big dogs, stay under the porch; little boats should stay close to shore; many go out for wool and come home shorn та ін.

In sum, the data suggest that implementing in speech a limited number of qualitative features of pessimism, proverbs used in pessimistic utterances contribute to speech realization of pessimistic attributional style and defensive pessimism. With all the findings, the current study needs to be further developed. The prospects touch upon the investigation of the phenomenon of pessimism in cognitive aspect.

\section{References:}

1. Коцюба 3.Г. Рефлексія побутової свідомості в різномовному провербіальному просторі (від універсального до національного): [монографія]. Львів : ВД «Укрпол», 2010. 472 с.

2. Abramson, L. Y., Seligman M. E. P., Teasdale J. D. Learned helplessness in people : Critique and reformulation. Journal of Abnormal Psychology. 1978. № 87. P. 49-74.

3. Berry S. R. An exploration of defensive pessimism, explanatory style, and expectations in relation to the academic performance of college and university students. PhD diss. University of Louisville, 2007. $128 \mathrm{p}$.

4. Cambridge International Dictionary of Idioms. Cambridge : Cambridge University Press, 1998. 587 p.

5. Collins Cobuild Dictionary of Idioms / ed. by J. Sinclair. Glasgow : HarperCollins Publishers, 1997. 493 p.

6. Oxford Dictionary of Idioms / ed. by J. Siefring. Oxford : Oxford University Press, 2004. 340 p.

7. Proverb. URL: https://www.britannica.com/art/proverb (Last accessed: 10.12.2017).

8. Strickland B. The Sign of the Sinister Sorcerer. Penguin, 2008. 176 p. 